\title{
RADIOCARBON DATES FOR LAVA FLOWS AND PYROCLASTIC DEPOSITS ON SÃO MIGUEL, AZORES
}

\author{
RICHARD B MOORE \\ US Geological Survey, Federal Center, MS 903, Denver, Colorado 80225 \\ and \\ MEYER RUBIN \\ US Geological Survey, National Center, MS 971, Reston, Virginia 22092

\section{INTRODUCTION}

We report 63 new radiocarbon analyses of samples from São Miguel, the largest (ca $62 \times$ $13 \mathrm{~km}$ ) and most populous (ca 150,000 inhabitants) island in the Azores archipelago (Fig 1). The samples are mainly carbonized tree roots and other plant material collected from beneath 20 mafic lava flows and spatter deposits and from within and beneath 42 trachytic pyroclastic flow, pyroclastic surge, mudflow, pumice-fall, and lacustrine deposits and lava flows. One calcite date is reported. The samples were collected during geologic mapping of the entire island (Moore, in press A; sample locations are shown on this map). Nine 1:25,000-scale topographic maps, published in 1983 by the Portuguese Army Cartographic Service, cover the island; samples and locations described below refer to these named sheets.

Six volcanic zones comprise São Miguel (Fig 2; Moore, in press B). From west to east, the zones are: 1) the trachyte stratovolcano of Sete Cidades; 2) a field of alkali basalt cinder cones and lava flows, with minor trachyte; 3) the trachyte stratovolcano of Agua de Pau; 4) a field of alkali basalt cinder cones and lava flows, with minor trachyte and tristanite; 5) the trachyte stratovolcano of Furnas and 6) the Nordeste shield volcano, which is mainly alkali basalt with minor trachyte. Rocks in Zones 1-5 are Quaternary in age, and rocks of the Nordeste shield volcano are Pleistocene and Pliocene in age (Moore, in press B). Charcoal was collected in volcanic Zones 1-5.

These dates establish ages for 48 previously undated lava flows and pyroclastic deposits, and revise three ages reported by Shotton, Blundell and Williams $(1968,1969)$ and Shotton and Williams (1971). The new dates provide limits on the ages of other units that lie above or below the dated units. These data are critical to deciphering the Holocene and late Pleistocene eruptive history of São Miguel and evaluating its potential volcanic hazards.

Average dormant intervals (Moore, in press B) during the past 3000 years are about 400 years for Sete Cidades volcano, 145 years for volcanic Zone 2, 1150 years for Agua de Pau volcano and 320 years for Furnas volcano. No known eruptions have occurred in volcanic Zone 4 during the past 3000 years.

Charcoal samples were analyzed at the Radiocarbon Laboratory of the US Geological Survey in Reston, Virginia. Pretreatment consisted of removal of modern rootlets and successive boiling in $\mathrm{HCl}, \mathrm{NaOH}$ and $\mathrm{HCl}$. Rinsing in distilled water followed each stage. The samples were converted to acetylene gas and their ${ }^{14} \mathrm{C}$ activity was measured in three different proportional gas counters. The error quoted includes the standard 1 sigma counting error plus known laboratory uncertainties. Ages are reported in years BP (1950) and were not corrected to a calendar date by tree-ring calibrations. All comments below are by RB Moore. 


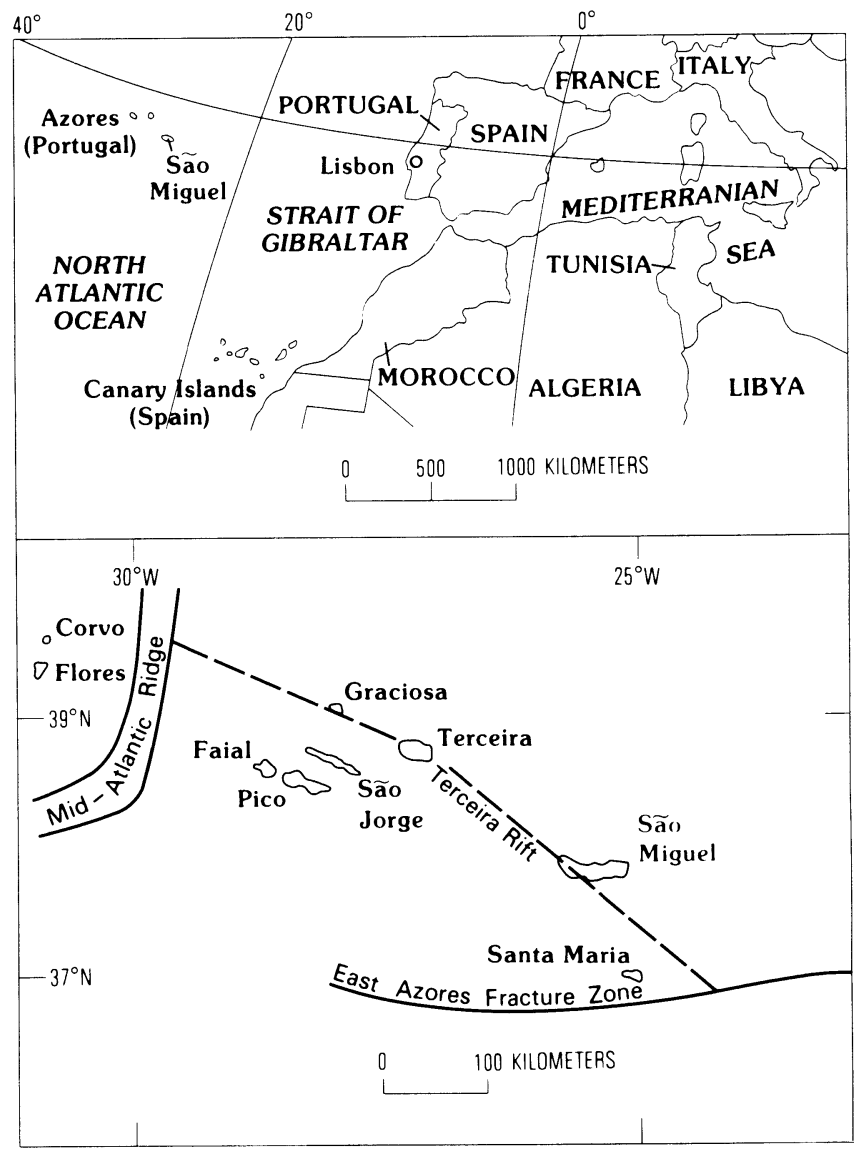

Fig 1. Index map of the Azores, after Moore (in press B)

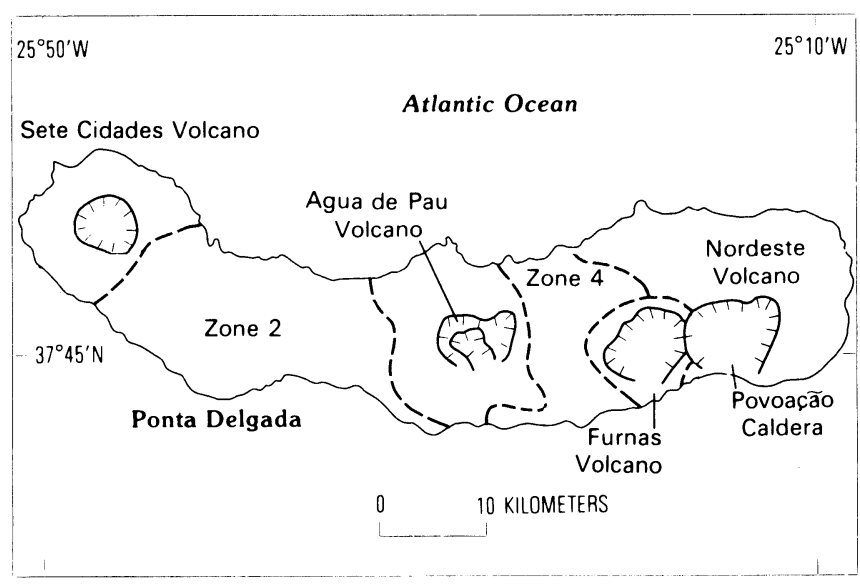

Fig 2. Index map of Sāo Miguel, showing its six volcanic zones, after Moore (in press B) 
W-5186. AD 1630 trachyte pumice deposit, Furnas volcano (Zone 5)

Charcoal fragments in mudflow deposit associated with most recent eruption of Furnas volcano (Weston 1964). Sample from roadcut on northeastern side of village of Furnas; altitude $250 \mathrm{~m}$; Povoação sheet $\left(37^{\circ} 47.02^{\prime} \mathrm{N}, 25^{\circ} 18.58^{\prime} \mathrm{W}\right)$. Coll 1981 by RB Moore.

Comment: within analytical uncertainty, date agrees with known age of $320 \mathrm{BP}$.

W-5264. AD 1630 trachyte pumice deposit, Furnas volcano (Zone 5)

$295 \pm 40$

Large charcoal fragments in pyroclastic flow deposit associated with AD 1630 Plinian fall deposits of Furnas volcano. Sample from roadcut $1.7 \mathrm{~km}$ south of Lagoa das Furnas; altitude $415 \mathrm{~m}$; Vila Franca do Campo sheet $\left(37^{\circ} 44.48^{\prime} \mathrm{N}, 25^{\circ} 20.59^{\prime} \mathrm{W}\right)$. Coll 1982 by RB Moore.

Comment: date agrees with known age of $320 \mathrm{BP}$.

W-5430. Sete L trachyte pumice deposit, Sete Cidades volcano (Zone 1) $\quad 500 \pm 100$

Charcoal fragments in lens at base of mudflow deposit interbedded with Sete L (terminology of Booth, Croasdale \& Walker 1978) trachyte pumice deposit. Sample from northern side of new roadcut $200 \mathrm{~m}$ west of village of Sete Cidades; altitude $270 \mathrm{~m}$; Candelaria sheet $\left(37^{\circ} 51.73^{\prime} \mathrm{N}\right.$, $\left.25^{\circ} 48.20^{\prime} \mathrm{W}\right)$. Coll 1983 by RB Moore and M Rubin.

Comment: date agrees with written records indicating that eruption of Sete Cidades was occurring at time of Portuguese discovery and initial settlement of the Azores ca AD 1444 (van Padang et al 1967). Shotton and Williams (1971) reported age of $663 \pm 105$ BP for Sete L.

\section{W-6175. Furnas G trachyte pumice deposit, Furnas volcano (Zone 5) $\quad 780 \pm 120$}

Charcoal fragments in trachyte pyroclastic flow deposit that is fourth highest unit in late Holocene pyroclastic sequence erupted from Furnas volcano. Sample from new roadcut on northern flank of Pico do Canario, on eastern rim of Furnas caldera; altitude $660 \mathrm{~m}$; Povoação sheet $\left(37^{\circ} 46.65^{\prime} \mathrm{N}, 25^{\circ} 16.79^{\prime} \mathrm{W}\right)$. Coll 1989 by RB Moore.

Comment: date establishes age of Furnas G deposit of Booth et al (1978).

W-5158. Pico das Camarinhas basanitoid cone, Sete Cidades volcano (Zone 1) $840 \pm 60$

Charcoal fragments at top of soil beneath scoria (basanitoid transitional to ankaramite) on eastern edge of Pico das Camarinhas cone. Scoria overlies trachyte dome and underlies Sete L deposit (Booth, Croasdale \& Walker 1978). Aa flow from cone formed Ponta da Ferraria lava delta, westernmost point on São Miguel. Sample from roadcut; altitude $160 \mathrm{~m}$; Candelaria sheet $\left(37^{\circ} 51.50^{\prime} \mathrm{N}, 25^{\circ} 50.89^{\prime} \mathrm{W}\right)$. Coll 1981 by RB Moore.

Comment: dates youngest subaerial mafic eruption on Sete Cidades volcano.

\section{W-5262. Basanitoid flow, Zone 2}

$980 \pm 90$

Charcoal fragments at top of soil beneath extensive basanitoid aa flow erupted from young spatter rampart (W-5161) southeast of Sete Cidades caldera. Flow entered ocean and built small lava deltas at three points west of village of Feteiras. Sample from roadcut in village of Biscoito; altitude $125 \mathrm{~m}$; Candelaria sheet $\left(37^{\circ} 48.59^{\prime} \mathrm{N}, 25^{\circ} 48.08^{\prime} \mathrm{W}\right)$. Coll 1982 by RB Moore and AMR da Silva.

Comment: W-5262 and -5161 agree well and establish age of this eruption at ca $1000 \mathrm{BP}$. 
W-6131. Mata das Feiticeiras basanitoid flow, Zone 2

$1010 \pm 120$

Charcoal fragments at top of soil beneath thin edge of extensive basanitoid aa flow from Mata das Feiticeiras spatter cone, in eastern part of Zone 2. Flow reached ocean and built large lava delta east of village of Rabo de Peixe. Sample from quarry on southwestern side of Pico da Cova; altitude $170 \mathrm{~m}$; Ponta Delgada sheet $\left(37^{\circ} 47.22^{\prime} \mathrm{N}, 25^{\circ} 34.00^{\prime} \mathrm{W}\right)$. Coll 1988 by RB Moore.

Comment: dates young prehistoric eruption.

W-5161. Basanitoid spatter, Zone 2

$1020 \pm 60$

Charcoal fragments at top of soil beneath basanitoid spatter that underlies Sete $\mathrm{L}$ deposit (Booth et al 1978). Sample from old roadcut cutting through western end of spatter rampart; altitude $670 \mathrm{~m}$ Candelaria sheet $\left(37^{\circ} 50.22^{\prime} \mathrm{N}, 25^{\circ} 46.29^{\prime} \mathrm{W}\right)$. Coll 1982 by RB Moore.

Comment: W-5161 and -5262 agree well and establish age of this young prehistoric eruption at ca 1000 BP.

W-6132. Trachyte maar, Zone 2

$1044 \pm 150$

Large charcoal fragments in coarse trachyte maar deposit. Maar, characterized by pyroclastic surge deposits and large $(1 \mathrm{~m})$ juvenile breadcrust bombs, formed at about same time as trachyte cone (W-6140) that caps Cruz cone ca $800 \mathrm{~m}$ to northwest. Sample from roadcut on southern side of Coroa da Furna spatter cone, near center of Zone 2; altitude 230m; Ponta Delgada sheet $\left(37^{\circ} 46.92^{\prime} \mathrm{N}, 25^{\circ} 37.37^{\prime} \mathrm{W}\right)$. Coll 1988 by RB Moore.

Comment: dates young explosive trachytic eruption only $500 \mathrm{~m}$ from Caldeirão electrical power plant, largest on São Miguel.

W-6140. Trachyte scoria, Cruz cone, Zone 2

$1100 \pm 150$

Charcoal fragments at top of soil beneath aphyric trachyte scoria near top of Cruz, cone near center of Zone 2. Sample from old roadcut on upper southern flank; altitude $360 \mathrm{~m}$; Ponta Delgada sheet $\left(37^{\circ} 47.40^{\prime} \mathrm{N}, 25^{\circ} 37.86^{\prime} \mathrm{W}\right)$. Coll 1988 by RB Moore.

Comment: date agrees well with W-6132 and establishes young age of this episode of trachytic volcanism in Zone 2.

W-5205. Furnas F trachyte pumice deposit, Furnas volcano (Zone 5) $\quad 1100 \pm 60$

Charcoal fragments in pyroclastic flow deposit correlated with the Furnas $F$ trachyte pumice deposit of Booth et al (1978). Sample from quarry $1.3 \mathrm{~km}$ east of Pico do Gaspar, trachyte dome that occupies vent for Furnas F deposit; quarry is $100 \mathrm{~m}$ west of paved road between villages of Furnas and Ribeira Quente; altitude 160m; Povoação sheet $\left(37^{\circ} 45.90^{\prime} \mathrm{N}, 25^{\circ} 18.00^{\prime} \mathrm{W}\right)$. Coll 1982 by RB Moore.

Comment: date agrees well with W-5435 and is important in determining average frequency of eruption of Furnas volcano during late Holocene time.

W-5435. Furnas F trachyte pumice deposit, Furnas volcano (Zone 5) $1120 \pm 110$

Carbonaceous soil immediately below base of Furnas F pumice deposit of Booth et al (1978). Location is same as W-5205. Coll 1983 by RB Moore and M Rubin.

Comment: date agrees well with W-5205. 
Charcoal fragments at top of soil beneath extensive basanitoid aa and pahoehoe flow from Pico das Mos, in southeastern part of Zone 2. Flow reached ocean at village of Lagoa. Sample from western side of small canyon on western side of Lamego spatter cone; altitude 140m; Ponta Delgada sheet $\left(37^{\circ} 45.65^{\prime} \mathrm{N}, 25^{\circ} 33.80^{\prime} \mathrm{W}\right)$. Coll 1989 by RB Moore.

Comment: dates young mafic eruption in Zone 2.

W-6149. Carvão basanitoid flow, Zone 2

$1280 \pm 150$

Charcoal fragments at top of soil beneath pahoehoe flow erupted from Pico do Carvão, in western part of Zone 2. Extensive flow is mostly aa and reached ocean at village of Capelas. Sample from roadcut in pasture; altitude $395 \mathrm{~m}$; Candelaria sheet $\left(37^{\circ} 49.08^{\prime} \mathrm{N}, 25^{\circ} 43.11^{\prime} \mathrm{W}\right)$. Coll 1988 by RB Moore.

Comment: Pico do Carvão and its flow are overlain only by 500-year-old Sete L trachyte pumice deposit of Booth et al (1978), indicating that Sete K erupted between 1860 BP (Sete J; W-5406) and $1280 \mathrm{BP}$ (Carvão).

W-6137. Caldeirão basanitoid flow, Zone 2

$1350 \pm 120$

Charcoal fragments at top of soil beneath extensive basanitoid aa flow erupted from unnamed cone only $20 \mathrm{~m}$ west of the Caldeirão electrical power plant, near center of Zone 2. Flow reached ocean at Praia do Populo. Sample from large quarry on western side of main road between Ponta Delgada and Ribeira Grande; altitude $180 \mathrm{~m}$; Ponta Delgada sheet $\left(37^{\circ} 46.60^{\prime} \mathrm{N}, 25^{\circ} 36.78^{\prime} \mathrm{W}\right)$. Coll 1988 by RB Moore.

Comment: dates young mafic eruption in Zone 2.

W-5433. Hawaiite flow, Zone 2

$1790 \pm 150$

Charcoal fragments at top of soil under hawaiite pahoehoe flow. Flow underlies western part of city of Ribeira Grande and formed lava delta where it entered ocean. Sample from edge of flow in small canyon $800 \mathrm{~m}$ west of Pico Vermelho, in northeastern part of Zone 2; altitude $130 \mathrm{~m}$; Ribeira Grande sheet $\left(37^{\circ} 48.00^{\prime} \mathrm{N}, 25^{\circ} 31.03^{\prime} \mathrm{W}\right)$. Coll 1983 by RB Moore and AMR da Silva.

Comment: dates extensive, relatively young flow and provides information on late Holocene average frequency of eruption in Zone 2.

W-5406. Sete J trachyte pumice deposit, Sete Cidades volcano (Zone 1) $1860 \pm 120$

Charcoal fragments in pyroclastic flow deposit associated with Sete J pumice deposit of Booth et al (1978). Sample from new roadcut at Vista do Rei on southern rim of Sete Cidades caldera; altitude $580 \mathrm{~m}$; Candelaria sheet $\left(37^{\circ} 50.30^{\prime} \mathrm{N}, 25^{\circ} 47.72^{\prime} \mathrm{W}\right)$. Coll 1983 by RB Moore.

Comment: dates third youngest explosive eruption of trachyte from Sete Cidades volcano and provides data for estimating the volcano's average frequency of eruption during late Holocene time.

W-6145. Pico da Furna basanitoid bombs, Zone 2

$2460 \pm 220$

Charcoal fragments at top of soil under large $(0.7 \mathrm{~m})$ basanitoid bombs from Pico da Furna, near center of Zone 2. Extensive flow from cone reached ocean between villages of Capelas and 
Fenais da Luz on northern coast of Zone 2. Sample from old roadcut on western flank of Pico Grande; altitude $260 \mathrm{~m}$; Ribeira Grande sheet $\left(37^{\circ} 48.15^{\prime} \mathrm{N}, 25^{\circ} 39.45^{\prime} \mathrm{W}\right)$. Coll 1988 by RB Moore.

Comment: dates relatively young eruption and provides data bearing on average frequency of eruption in Zone 2.

\section{W-5265. Eguas ankaramite bombs, Zone 2}

$2700 \pm 250$

Charcoal fragments at top of soil beneath large $(1 \mathrm{~m})$ ankaramite bombs from Eguas cone, in western part of Zone 2. Sample from roadcut $1.6 \mathrm{~km}$ southeast of Sete Cidades caldera; altitude $720 \mathrm{~m}$; Candelaria sheet $\left(37^{\circ} 49.85^{\prime} \mathrm{N}, 25^{\circ} 45.30^{\prime} \mathrm{W}\right)$. Coll 1982 by RB Moore.

Comment: Eguas cone erupted an extensive ankaramite flow that covers much of western part of Zone 2 and reached ocean near village of Feteiras. Date is important for stratigraphy and determination of average frequency of eruption in this area.

W-6143. Basanitoid cone, Zone 2

$2800 \pm 120$

Charcoal fragments at top of soil beneath basanitoid bombs from prominent cone between Picos de Lima and Pico Grande, near center of Zone 2. Thick, extensive flow was erupted from this vent. Sample from old roadcut in pasture where large $(0.5 \mathrm{~m})$ bombs fell on northwestern flank of Picos de Lima; altitude 320m; Ponta Delgada sheet $\left(37^{\circ} 47.75^{\prime} \mathrm{N}, 25^{\circ} 38.88^{\prime} \mathrm{W}\right)$. Coll 1988 by RB Moore.

Comment: date is important for stratigraphy and determination of average frequency of eruption in this area.

W-5414. Lagoa do Congro trachyte maar, Zone 4

$3800 \pm 400$

Charcoal fragments at top of soil underlying coarse $(0.3 \mathrm{~m})$ trachyte pumice in basal pyroclastic flow deposit from Lagoa do Congro, near center of Zone 4. Sample from canyon $300 \mathrm{~m}$ west of Lagoa do Congro; altitude 500m; Vila Franca do Campo sheet $\left(37^{\circ} 45.65^{\prime} \mathrm{N}, 25^{\circ} 24.83^{\prime} \mathrm{W}\right)$. Coll 1983 by RB Moore.

Comment: date is in accordance with age inferred by Booth et al (1978) on basis of soil development and stratigraphy of trachyte pumice deposits from Agua de Pau volcano. Lagoa do Congro is second youngest volcanic vent in Zone 4.

\section{W-6174. East Congro trachyte maar, Zone 4}

$4160 \pm 160$

Large charcoal fragments in trachyte pyroclastic flow deposit associated with small maar $0.7 \mathrm{~km}$ east of Lagoa do Congro, near center of Zone 4. Sample from northeastern wall of shallow maar crater; altitude $490 \mathrm{~m}$; Vila Franca do Campo sheet $\left(37^{\circ} 45.60^{\prime} \mathrm{N}, 25^{\circ} 23.85^{\prime} \mathrm{W}\right)$. Coll 1989 by RB Moore.

Comment: date is similar to W-5414, indicating that this deposit was emplaced at about same time that Lagoa do Congro erupted.

W-5424. Fogo A trachyte pumice deposit, Agua de Pau volcano (Zone 3) $\quad 4480 \pm 180$

Large charcoal fragments in trachyte pyroclastic flow deposit associated with Fogo A Plinian deposit from Agua de Pau volcano (Walker \& Croasdale 1970). Sample from quarry in ankaramite spatter cone that underlies Fogo $\mathrm{A}$ on northwestern side of main road $2.5 \mathrm{~km}$ northeast of village 
of Remedios, on western flank of Agua de Pau volcano; altitude 550m; Ponta Delgada sheet $\left(37^{\circ} 45.88^{\prime} \mathrm{N}, 25^{\circ} 31.08^{\prime} \mathrm{W}\right)$. Coll 1983 by RB Moore.

Comment: date is one of nine new determinations, reported here, of age of charcoal from separate locations within Fogo A deposit. Shotton et al $(1968,1969)$ reported ages of $4435 \pm 99$ and 4672 $\pm 100 \mathrm{BP}$ for Fogo A; nine new dates average $4936 \mathrm{BP}$, nearly 400 years more than average of determinations by Shotton et al. Range in mean ages (900 years) suggests that Fogo A may be product of more than one eruption.

W-5436. Fogo A trachyte pumice deposit, Agua de Pau volcano (Zone 3) $\quad 4700 \pm 200$

Charcoal fragments in trachyte pyroclastic flow deposit associated with Fogo A Plinian deposit. Sample from old roadcut in Ribeira Grande canyon $1.8 \mathrm{~km}$ southeast of village of Caldeiras, on northern flank of Agua de Pau volcano; altitude 550m; Vila Franca do Campo sheet $\left(37^{\circ} 47.42^{\prime} \mathrm{N}, 25^{\circ} 28.47^{\prime} \mathrm{W}\right)$. Coll 1983 by RB Moore.

Comment: dates pyroclastic flow deposit within Fogo A sequence.

W-5438. Fogo A trachyte pumice deposit, Agua de Pau volcano (Zone 3) $4700 \pm 180$

Charcoal fragments in trachyte pyroclastic surge deposit associated with Fogo A Plinian deposit. Sample from roadcut $0.9 \mathrm{~km}$ northwest of village of Agua de Alto, on southern flank of Agua de Pau volcano; altitude $210 \mathrm{~m}$; Vila Franca do Campo sheet $\left(37^{\circ} 43.95^{\prime} \mathrm{N}, 25^{\circ} 27.79^{\prime} \mathrm{W}\right)$. Coll 1983 by RB Moore.

Comment: dates pyroclastic surge deposit within Fogo A sequence.

W-5434. Fogo A trachyte pumice deposit, Agua de Pau volcano (Zone 3) $\quad 4890 \pm 150$

Charcoal fragments at base of basal trachyte Plinian deposit of Fogo A. Sample from roadcut $1.4 \mathrm{~km}$ northeast of village of Ribeira Chã, on southern flank of Agua de Pau volcano; altitude $310 \mathrm{~m}$ Vila Franca do Campo sheet $\left(37^{\circ} 44.29^{\prime} \mathrm{N}, 25^{\circ} 28.70^{\prime} \mathrm{W}\right)$. Coll 1983 by RB Moore.

Comment: dates basal Plinian deposit of Fogo A eruption.

W-5426. Fogo A trachyte pumice deposit, Agua de Pau volcano (Zone 3) $4960 \pm 180$

Large charcoal fragments in trachyte pyroclastic surge deposit associated with Fogo A Plinian deposit. Sample from trail in Ribeira Grande canyon on northern flank of Agua de Pau volcano; altitude 470m; Vila Franca do Campo sheet $\left(37^{\circ} 47.39^{\prime} \mathrm{N}, 25^{\circ} 28.73^{\prime} \mathrm{W}\right)$. Coll 1983 by RB Moore.

Comment: dates pyroclastic surge deposit within Fogo A sequence.

W-5251. Monte Gordo-Ribeirinha hybrid basalt flow,

$4990 \pm 100$ Agua de Pau volcano (Zone 3)

Charcoal fragments at top of thin soil underlying extensive flow of hybrid basalt. Flow appears to be underlain and overlain by pumice-fall deposits associated with the Fogo A eruption. Flow came from spatter cone at Monte Gordo on northern flank of Agua de Pau volcano. Sample from top of sea cliff $1.9 \mathrm{~km}$ northeast of city of Ribeira Grande; altitude $50 \mathrm{~m}$; Ribeira Grande sheet $\left(37^{\circ} 50.47^{\prime} \mathrm{N}, 25^{\circ} 30.30^{\prime} \mathrm{W}\right)$. Coll 1981 by RB Moore and AMR da Silva.

Comment: dates important stratigraphic unit interbedded with Fogo A trachyte pumice deposit. Rise of mafic magma may have initiated Fogo A eruption; mafic magma may have mixed with 
trachytic magma at margins of trachytic magma reservoir, leading to hybrid composition of this flow.

W-5437. Fogo A trachyte pumice deposit, Agua de Pau volcano (Zone 3) $\quad 5020 \pm 200$

Charcoal fragments in trachyte pyroclastic surge deposit associated with Fogo A Plinian deposit. Sample from roadcut $0.9 \mathrm{~km}$ north-northwest of village of Agua de Alto, on southern flank of Agua de Pau volcano; altitude $280 \mathrm{~m}$; Vila Franca do Campo sheet $\left(37^{\circ} 44.12^{\prime} \mathrm{N}, 25^{\circ} 27.60^{\prime} \mathrm{W}\right)$. Coll 1983 by RB Moore.

Comment: dates pyroclastic surge deposit within Fogo A sequence; underlies W-5438.

W-5411. Fogo A trachyte pumice deposit, Agua de Pau volcano (Zone 3) $\quad 5140 \pm 180$

Charcoal fragments in trachyte pyroclastic flow deposit associated with Fogo A Plinian deposit. Sample from roadcut $4 \mathrm{~km}$ southwest of village of Porto Formoso, on northern flank of Agua de Pau volcano; altitude $480 \mathrm{~m}$; Maia sheet $\left(37^{\circ} 47.90^{\prime} \mathrm{N}, 25^{\circ} 27.78^{\prime} \mathrm{W}\right)$. Coll 1983 by RB Moore.

Comment: dates pyroclastic flow deposit within Fogo A sequence.

W-5257. Fogo A trachyte pumice deposit, Agua de Pau volcano (Zone 3) $\quad 5150 \pm 120$

Charcoal fragments in trachyte pyroclastic flow deposit associated with Fogo A Plinian deposit. Sample from roadcut $200 \mathrm{~m}$ east of village of Ribeira Chã, on southern flank of Agua de Pau volcano; altitude 150m; Vila Franca do Campo sheet $\left(37^{\circ} 43.60^{\prime} \mathrm{N}, 25^{\circ} 29.05^{\prime} \mathrm{W}\right)$. Coll 1981 by RB Moore.

Comment: dates pyroclastic flow deposit within Fogo A sequence.

W-5431. Fogo A trachyte pumice deposit, Agua de Pau volcano (Zone 3) $\quad \mathbf{5 3 8 0} \pm 210$

Charcoal fragments in trachyte pyroclastic flow deposit associated with Fogo A Plinian deposit. Sample from small quarry on northeastern side of main road $4.5 \mathrm{~km}$ north of village of Vila Franca do Campo; altitude 520m; Vila Franca do Campo sheet $\left(37^{\circ} 45.68^{\prime} \mathrm{N}, 25^{\circ} 26.00^{\prime} \mathrm{W}\right)$. Coll 1983 by RB Moore.

Comment: date is oldest for Fogo A deposit.

W-5190. Lake sediments, Furnas volcano (Zone 5)

$6520 \pm 100$

Black carbonaceous lake sediments associated with mudflow deposit on floor of caldera of Furnas volcano. Sample from small excavation $0.7 \mathrm{~km}$ east of main fumaroles in village of Furnas; altitude $186 \mathrm{~m}$; Povoação sheet $\left(37^{\circ} 46.70^{\prime} \mathrm{N}, 25^{\circ} 17.82^{\prime} \mathrm{W}\right)$. Coll 1982 by RB Moore.

Comment: date indicates time of deposition of sediments in small pond that may have formed when pyroclastic flows and associated mudflows dammed ancestral Ribeira Quente (Hot River). Source of pyroclastic deposits may have been Pico do Canario, post-caldera tristanite cone on eastern caldera rim $1.3 \mathrm{~km}$ east of sample location.

W-5420. Pico do João Fernandes ankaramite cone, Zone 2

$8700 \pm 200$

Charcoal fragments at top of soil underlying ankaramite scoria of Pico do João Fernandes, cone in southeastern part of Zone 2. Sample from small excavation $1.6 \mathrm{~km}$ north of village of 
Remedios; altitude $310 \mathrm{~m}$; Ponta Delgada sheet $\left(37^{\circ} 45.89^{\prime} \mathrm{N}, 25^{\circ} 32.20^{\prime} \mathrm{W}\right)$. Coll 1983 by RB Moore.

Comment: dates largest in a group of ankaramite cones and provides data bearing on average frequency of eruption in Zone 2.

W-5247. Hawaiite cone, Cerrado dos Bezerros, Zone 4

$10,620 \pm 300$

Charcoal fragments at top of soil underlying aphyric hawaiite scoria of relatively old cone at Cerrado dos Bezerros, in southeastern part of Zone 4. Sample from roadcut; altitude 540m; Vila Franca do Campo sheet $\left(37^{\circ} 45.20^{\prime} \mathrm{N}, 25^{\circ} 22.00^{\prime} \mathrm{W}\right)$. Coll 1982 by RB Moore.

Comment: date provides information about average frequency of eruption in Zone 4.

W-5160. Trachyte dome, Pico do Ferro, Furnas volcano (Zone 5)

$11,230 \pm 100$

Charcoal fragments at top of soil beneath glassy, pumiceous base of Pico do Ferro trachyte dome, on western rim of caldera of Furnas volcano. Underlying soil, 10-cm-thick, is developed on welded pyroclastic flows and associated pumice-fall deposits of caldera-outflow deposit. Sample from caldera wall; altitude $480 \mathrm{~m}$; Vila Franca do Campo sheet $\left(37^{\circ} 46.74^{\prime} \mathrm{N}, 25^{\circ} 20.12^{\prime} \mathrm{W}\right)$. Coll 1982 by RB Moore.

Comment: dates group of post-caldera domes and provides approximate age of 12,000 years for formation of the caldera of Furnas volcano.

W-5172. Trachyte pumice, younger caldera-outflow deposit, $15,180 \pm 150$ Agua de Pau volcano (Zone 3)

Charcoal fragments at top of soil beneath canyon-filling, locally welded, trachyte pyroclastic flow deposit on southern flank of Agua de Pau volcano. Sample from roadcut $300 \mathrm{~m}$ south of village of Ribeira Chã; altitude 20m; Vila Franca do Campo sheet $\left(37^{\circ} 43.23^{\prime} \mathrm{N}, 25^{\circ} 29.39^{\prime} \mathrm{W}\right)$. Coll 1982 by RB Moore.

Comment: dates formation of inner caldera of Agua de Pau volcano and agrees with W-5416.

W-5416. Trachyte pumice, younger caldera-outflow deposit, $\quad 15,190 \pm 280$ Agua de Pau volcano (Zone 3)

Charcoal fragments at top of soil beneath coarse basal trachyte pumice of younger caldera-outflow deposit from Agua de Pau volcano. Sample from small canyon $400 \mathrm{~m}$ west of village of Ribeira Chã on southern flank of Agua de Pau volcano; altitude 100m; Vila Franca do Campo sheet $\left(37^{\circ} 43.34^{\prime} \mathrm{N}, 25^{\circ} 29.73^{\prime} \mathrm{W}\right)$. Coll 1983 by RB Moore.

Comment: dates formation of inner caldera of Agua de Pau volcano and agrees with W-5172.

W-5165. Trachyte pyroclastic flow deposit, Sete Cidades volcano (Zone 1) $17,160 \pm 130$

Charcoal fragments in pyroclastic flow deposit associated with trachyte domes and flows on northern side of village of Ginetes, on western flank of Sete Cidades volcano. Sample from top of sea cliff beneath overlook $500 \mathrm{~m}$ west of Escalvado cone; altitude $210 \mathrm{~m}$; Candelaria sheet $\left(37^{\circ} 52.30^{\prime} \mathrm{N}, 25^{\circ} 50.72^{\prime} \mathrm{W}\right)$. Coll 1982 by RB Moore.

Comment: dates major post-caldera flank eruption of Sete Cidades volcano. 
W-5409. Coroa da Mata trachyte pumice ring, Agua de Pau volcano (Zone 3)

Large charcoal fragments in pyroclastic flow deposit in pumice ring surrounding Coroa da Mata trachyte dome, on northern flank of Agua de Pau volcano. Ring overlies older calderaoutflow deposit from Agua de Pau. Sample from roadcut $2.2 \mathrm{~km}$ east of village of Ribeirinha; altitude $210 \mathrm{~m}$; Maia sheet $\left(37^{\circ} 49.54^{\prime} \mathrm{N}, 25^{\circ} 28.42^{\prime} \mathrm{W}\right)$. Coll 1983 by RB Moore.

Comment: dates major flank eruption and provides minimum age for formation of outer caldera of Agua de Pau volcano.

W-5189. Mugearite flow, Zone 2

$20,890 \pm 240$

Charcoal fragments at top of soil beneath aphyric mugearite aa flow. Sample from roadcut on northwestern side of village of Feteiras, in western part of Zone 2; altitude $140 \mathrm{~m}$; Candelaria sheet $\left(37^{\circ} 48.30^{\prime} \mathrm{N}, 25^{\circ} 47.55^{\prime} \mathrm{W}\right)$. Coll 1981 by RB Moore and AMR da Silva.

Comment: date combined with stratigraphy provides information about average frequency of eruption in Zone 2.

W-5170. Tristanite scoria, Sete Cidades volcano (Zone 1)

$21,160 \pm 180$

Charcoal fragments at top of soil beneath coarse tristanite scoria on northwestern wall of caldera of Sete Cidades volcano. Soil with charcoal is developed on similar deposit of tristanite scoria which, in turn, rests on Sete Cidades caldera-outflow deposit. Sample from roadcut $1.7 \mathrm{~km}$ northwest of village of Sete Cidades; altitude $420 \mathrm{~m}$; Candelaria sheet $\left(37^{\circ} 52.39^{\prime} \mathrm{N}, 25^{\circ} 48.82^{\prime} \mathrm{W}\right)$. Coll 1982 by RB Moore.

Comment: date provides approximate age of $22,000 \mathrm{BP}$ for formation of caldera of Sete Cidades volcano, based on thicknesses of soils separating W-5170 from caldera-outflow deposit and comparison with soils developed on historic (AD 1563 Agua de Pau and AD 1630 Furnas) trachyte pumice deposits on São Miguel.

W-5188. Trachyte mudflow deposit, Furnas volcano (Zone 5)

$22,060 \pm 250$

Charcoal and carbonaceous material in trachyte mudflow deposit, interpreted as hot during emplacement. Overlies W-5168 and -5249. Sample from base of sea cliff on southern flank of Furnas volcano; altitude $8 \mathrm{~m}$; Povoação sheet $\left(37^{\circ} 43.88^{\prime} \mathrm{N}, 25^{\circ} 19.18^{\prime} \mathrm{W}\right)$. Coll 1981 by RB Moore.

Comment: dates thick $(40 \mathrm{~m})$ deposit near base of stratigraphic section on southern coast and illustrates young age of Furnas volcano, which has been constructed entirely within past 100,000 years.

\section{W-5259. Carbonaceous lake sediments, Furnas volcano (Zone 5) $\quad 23,000 \pm 1000$}

Fossiliferous, carbonaceous, thinly-bedded lacustrine sediments, mainly consisting of trachyte ash, on western wall of Furnas caldera. Lake probably occupied pre-caldera volcanic crater. Fossils include five species of shallow freshwater diatoms (J Platt Bradbury, written commun 1984). Three separate lacustrine deposits, separated by lava flows, were dated (W-5259, -5192 , -5253 , and -5441) and yielded ages from 23,000-27,000 BP. Sample from small canyon at base of caldera wall 500m northwest of Lagoa das Furnas; altitude 360m; Vila Franca do Campo sheet $\left(37^{\circ} 46.45^{\prime} \mathrm{N}, 25^{\circ} 20.30^{\prime} \mathrm{W}\right)$. Coll 1981 by RB Moore. 
Comment: W-5259 is in middle of three dated carbonaceous beds. Date establishes age of interbedded lava flows. Lake sediments underlie W-5160 (Pico do Ferro) and ca 12,000-year-old caldera-outflow deposit, and overlie trachyte flow dated by K-Ar at 48,000 $\pm 4000 \mathrm{BP}$ (EH McKee, written commun 1983).

\section{W-5192. Carbonaceous lake sediments, Furnas volcano (Zone 5) 24,000 \pm 500}

Lowest of three dated carbonaceous beds. Sample location and collector are same as W-5259

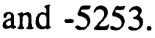

Comment: date agrees well with others from this site.

W-5441. Carbonaceous lake sediments, Furnas volcano (Zone 5)

Highest of three dated carbonaceous beds. Sample location is same as W-5259, -5192 and -5253. Coll 1983 by RB Moore and M Rubin.

Comment: sample is recollection of W-5253; dates are in accordance.

W-5427. Basanitoid flow, Zone 4

$26,500 \pm 500$

Basanitoid aa flow in northwestern part of Zone 4. Sample from roadcut $500 \mathrm{~m}$ southeast of village of Porto Formoso; altitude $160 \mathrm{~m}$; Maia sheet $\left(37^{\circ} 49.25^{\prime} \mathrm{N}, 25^{\circ} 25.60^{\prime} \mathrm{W}\right)$. Coll 1983 by RB Moore.

Comment: dates relatively old flow in Zone 4.

W-5253. Carbonaceous lake sediments, Furnas volcano (Zone 5) $\quad 27,000 \pm 1000$

Highest of three dated carbonaceous beds. Sample location is same as W-5259, -5192 and -5441. Coll 1981 by RB Moore.

Comment: date agrees with W-5441.

W-5175. Trachyte pumice deposit, Sete Cidades volcano (Zone 1)

$>29,000$

Charcoal fragments in trachyte pyroclastic flow deposit. Sampled unit is third from bottom in section of interbedded lava flows and pyroclastic deposits. Sample from sea cliff near Ponta da Ferraria on western end of São Miguel; altitude 10m; Candelaria sheet (37 $51.46^{\prime} \mathrm{N}$, $25^{\circ} 51.28^{\prime} \mathrm{W}$ ). Coll 1981 by RB Moore and AMR da Silva.

Comment: most charcoal samples within pyroclastic flow deposits and under lava flows in Ponta da Ferraria section are too old to date by radiocarbon; they overlie tristanite flow dated by K-Ar at 74,000 $\pm 6000 \mathrm{BP}$ (EH McKee, written commun 1983).

\section{W-6151. Basanitoid cone, Zone 2}

Large soft charcoal fragments at top of soil underlying welded basanitoid spatter. Sample from new excavation $1.5 \mathrm{~km}$ west of Serra Gorda, in west-central part of Zone 2; altitude $320 \mathrm{~m}$; Arrifes sheet $\left(37^{\circ} 47.49^{\prime} \mathrm{N}, 25^{\circ} 42.47^{\prime} \mathrm{W}\right)$. Coll 1988 by RB Moore.

Comment: dates one of oldest cones in Zone 2. Sampled unit underlies caldera-outflow deposit from Sete Cidades volcano, four trachyte pumice deposits and two basaltic cinder deposits. 
W-5176. Trachyte pumice deposit, Sete Cidades volcano (Zone 1)

$>33,000$

Charcoal fragments in pyroclastic flow deposit near middle of section near Ponta da Ferraria. Sampled unit is higher in section than W-5175. Sample from trail on sea cliff; altitude $90 \mathrm{~m}$; Candelaria sheet $\left(37^{\circ} 51.70^{\prime} \mathrm{N}, 25^{\circ} 51.18^{\prime} \mathrm{W}\right)$. Coll 1981 by RB Moore.

Comment: this date and others in Ponta da Ferraria section indicate relatively old age of this part of Sete Cidades volcano.

W-5168. Trachyte pumice deposit, Furnas volcano (Zone 5) $>\mathbf{3 3 , 0 0 0}$

Large soft charcoal fragments in trachyte pyroclastic flow deposit near base of section on southern flank of Furnas volcano. Sample from sea cliff $1.3 \mathrm{~km}$ west of village of Ribeira Quente; altitude 5m; Povoação sheet $\left(37^{\circ} 44.15^{\prime} \mathrm{N}, 25^{\circ} 18.90^{\prime} \mathrm{W}\right)$. Coll 1981 by RB Moore.

Comment: this deposit, W-5249 and -5188 overlie tristanite flow, dated by K-Ar at 93,000 \pm 9000 BP (EH McKee, written commun 1983), at base of section west of Ribeira Quente.

W-5249. Trachyte pumice deposit, Furnas volcano (Zone 5) $>\mathbf{3 4 , 0 0 0}$

Charcoal fragments in trachyte pyroclastic surge deposit overlying W-5168. Sample location and collector are same as W-5168.

Comment: unit underlies W-5188, dated at $22,060 \pm 250 \mathrm{BP}$.

W-5428. Calcite, PV-1 geothermal well, Zone 2

$>36,000$

Calcite precipitate at geothermal wellhead. Sample from PV-1 well, drilled in 1980-1981, $2.5 \mathrm{~km}$ southeast of city of Ribeira Grande, in northeastern part of Zone 2; altitude $152 \mathrm{~m}$; Ribeira Grande sheet $\left(37^{\circ} 48.24^{\prime} \mathrm{N}, 25^{\circ} 30.53^{\prime} \mathrm{W}\right)$. Coll 1983 by AMR da Silva.

Comment: date indicates old age of carbon dioxide that has been produced from geothermal reservoir beneath Agua de Pau volcano.

W-5201. Tristanite flow, Agua de Pau volcano (Zone 3)

$>40,000$

Charcoal fragments at top of soil beneath tristanite flow. Sampled unit is lowest flow in thick, mainly pyroclastic, sequence on southern flank of Agua de Pau volcano; sequence overlies trachyte dome dated by K-Ar at 181,000 $\pm 15,000 \mathrm{BP}$ (Gandino et al 1985). Sample from sea cliff $400 \mathrm{~m}$ southeast of village of Ribeira Chã, on southern flank of Agua de Pau volcano; altitude $30 \mathrm{~m}$; Vila Franca do Campo sheet $\left(37^{\circ} 43.35^{\prime} \mathrm{N}, 25^{\circ} 29.00^{\prime} \mathrm{W}\right)$. Coll 1981 by RB Moore.

Comment: dates flow between Units 4 and 5 of Booth, Croasdale and Walker (1978) and agrees with age of $>34,200$ years reported by Shotton and Williams (1973) for Unit 14 of Booth, Croasdale and Walker (1978).

\section{W-5243. Trachyte pumice, Agua de Pau volcano (Zone 3)}

$>40,000$

Charcoal fragments in trachyte pyroclastic flow deposit. Sample from roadcut $1.3 \mathrm{~km}$ west of village of Porto Formoso, on northern flank of Agua de Pau volcano; altitude $50 \mathrm{~m}$; Maia sheet $\left(37^{\circ} 49.63^{\prime} \mathrm{N}, 25^{\circ} 27.04^{\prime} \mathrm{W}\right)$. Coll 1982 by RB Moore and AMR da Silva.

Comment: dates old pyroclastic flow deposit from Agua de Pau volcano. Sampled unit overlies welded tuffs dated by K-Ar at 103,000 $\pm 7000 \mathrm{BP}$ (Gandino et al 1985). 


\section{W-5173. Hawaiite flow, Sete Cidades volcano (Zone 1)}

Charcoal fragments at top of soil beneath thick $(23 \mathrm{~m})$ hawaiite aa flow. Sample from sea cliff $500 \mathrm{~m}$ southwest of village of Candelaria on southwestern flank of Sete Cidades volcano; altitude $15 \mathrm{~m}$; Candelaria sheet $\left(37^{\circ} 49.20^{\prime} \mathrm{N}, 25^{\circ} 49.72^{\prime} \mathrm{W}\right)$. Coll 1982 by RB Moore.

Comment: dates flow that underlies caldera-outflow deposit from Sete Cidades volcano.

W-5179. Trachyte pumice deposit, Sete Cidades volcano (Zone 1)

Charcoal fragments in trachyte pyroclastic flow deposit near Ponta da Ferraria on western end of São Miguel. Unit overlies W-5175. Sample from sea cliff; altitude $15 \mathrm{~m}$; Candelaria sheet $\left(37^{\circ} 51.46^{\prime} \mathrm{N}, 25^{\circ} 51.28^{\prime} \mathrm{W}\right)$. Coll 1981 by RB Moore and AMR da Silva.

Comment: dates old pyroclastic flow deposit on western flank of Sete Cidades volcano.

\section{W-5183. Trachyte mudflow deposit, Sete Cidades volcano (Zone 1) $\quad>40,000$}

Charcoal fragments in trachyte mudflow deposit. Unit overlies W-5175 and underlies -5179 . Sample location and collectors are same as W-5175 and -5179 . Altitude $11 \mathrm{~m}$.

Comment: mudflow deposit presumably was hot when emplaced.

W-5193. Mugearite flow, Sete Cidades volcano (Zone 1)

Charcoal fragments in soil $15 \mathrm{~cm}$ below base of mugearite flow. Unit underlies W-5176. Sample from sea cliff near Ponta da Ferraria on western end of São Miguel; altitude $55 \mathrm{~m}$; Candelaria sheet $\left(37^{\circ} 51.70^{\prime} \mathrm{N}, 25^{\circ} 51.18^{\prime} \mathrm{W}\right)$. Coll 1981 by RB Moore.

Comment: mugearite flows are common in Ponta da Ferraria section and apparently were erupted between 74,000 and ca 40,000 years.

\section{W-5194. Trachyte pumice deposit, Sete Cidades volcano (Zone 1) $>40,000$}

Charcoal fragments in trachyte pyroclastic flow deposit. Sample from sea cliff $1.3 \mathrm{~km}$ west-northwest of village of Feteiras on southern flank of Sete Cidades volcano; altitude $30 \mathrm{~m}$; Candelaria sheet $\left(37^{\circ} 48.50^{\prime} \mathrm{N}, 25^{\circ} 48.76^{\prime} \mathrm{W}\right)$. Coll 1982 by WA Duffield and RB Moore.

Comment: dates old pyroclastic flow deposit from Sete Cidades volcano.

\section{W-5199. Trachyte pumice deposit, Sete Cidades volcano (Zone 1) $>40,000$}

Charcoal fragments in pyroclastic flow deposit. Sample from southwestern wall of caldera of Sete Cidades volcano, $700 \mathrm{~m}$ northwest of Vista do Rei; altitude $420 \mathrm{~m}$; Candelaria sheet $\left(37^{\circ} 50.60^{\prime} \mathrm{N}, 25^{\circ} 48.21^{\prime} \mathrm{W}\right)$. Coll 1982 by RB Moore.

Comment: dates old pre-caldera pyroclastic flow deposit from Sete Cidades volcano.

W-5206. Mugearite flow, Sete Cidades volcano (Zone 1)

Charcoal fragments at top of soil under mugearite flow. Sample from small canyon $1.3 \mathrm{~km}$ southwest of village of Mosteiros on northwestern flank of Sete Cidades volcano; altitude $80 \mathrm{~m}$; Candelaria sheet $\left(37^{\circ} 52.78^{\prime} \mathrm{N}, 25^{\circ} 49.95^{\prime} \mathrm{W}\right)$. Coll 1981 by RB Moore.

Comment: date agrees well with other old ages of mugearite and associated hawaiite flows (W-5173, -5193) on western flank of Sete Cidades volcano. 


\section{ACKNOWLEDGMENTS}

We thank Lea Gargulinski and John McGeehin, USGS, Reston, for sample preparation and treatment. AMR da Silva of the Regional Government of the Azores gave considerable logistical support. We thank JE Quick and CR Thornber for their helpful reviews of the manuscript.

\section{REFERENCES}

Booth, B, Croasdale, R and Walker, GPL 1978 A quantitative study of five thousand years of volcanism on São Miguel, Azores. Royal Soc [London] Philos Trans 288: 271-319.

Gandino, A, Guidi, M, Merlo, C, Mete, L, Rossi, R and Zan, L 1985 Preliminary model of the Ribeira Grande geothermal field (Azores Islands). Geothermics 14: 91-105.

Moore, RB, in press A, Geologic map of São Miguel, Azores. US Geol Survey Misc Inv Map I-2007, scale 1:50,000. in press B, Volcanic geology and eruption frequency, São Miguel, Azores. Bull Volcanol.

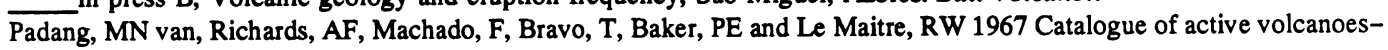
Atlantic Ocean. Internatl Volcanol Assoc 21.

Shotton, FW, Blundell, DJ and Williams, REG 1968 Birmingham University radiocarbon dates II. Radiocarbon 10(2): 200-206.

1969 Birmingham University radiocarbon dates III. Radiocarbon 11(2): 263-270.

Shotton, FW and Williams, REG 1971 Birmingham University radiocarbon dates V. Radiocarbon 13(2): 141-156. 1973 Birmingham University radiocarbon dates VII. Radiocarbon 15(3): 451-468.

Walker, GPL and Croasdale, R 1970 Two Plinian-type eruptions in the Azores. Jour Geol Soc London 127: 17-55.

Weston, FS 1964 List of recorded volcanic eruptions in the Azores with brief reports. Bol Mus Lab Min Geol Fac Cien 10: 3-18. 